\title{
Health Care between Medicine and Religion The Case of Catholic Western Germany around 1800
}

\author{
Walter Bruchhausen
}

$\mathrm{T}$

The relationship between medicine and religion belongs to the classical topics of medical history, in the studies of the so called early civilizations, mainly oriental Middle Ages and of the European ealy modern period. Yet about a century ago, preformed by enlightenment ideas on linear progress of humankind and often explicitly following Auguste Comte's cultural evolution theory of human development from magic via religion to science, many historians and sociologists dismissed any important role of religion in and for modern society. This was especially true for the view of health, illness and healing and has influenced the writing of medical history until today. Hence the period since the eighteenth century has been almost exclusively treated as an era with obvious characteristics: by that time science seemed to have excluded religion from medicine.

In Western societies during the last decades we should notice a phenomenon contrary to this alleged universal progress from religion to science. It was predicted early by the sociologist Peter L. Berger ${ }^{1}$, recently also taken up by the leading social philosopher Jürgen Habermas ${ }^{2}$, and received titles such as "the return of religion" and "desecularization" (Berger) ${ }^{3}$, the "re-enchantment of the world" (a reversal of Max Weber's observations) and "postsecular world" (Habermas). The mere fact of this revival, which - not only in the forms of New Age esotericism, but also in more charismatic and spiritual movements within the Christian churches - concerns also healing centrally, already by itself justifies a new look at the historical relationship

1 Peter L. Berger, A rumour of angels. Modern society and the rediscovery of the supernatural (London, 1970).

2 Jürgen Habermas, Glauben und Wissen. Friedenspreis des Deutschen Buchhandels 2001 (Frankfurt/M., 2001).

3 Peter L. Berger, ed., The desecularization of the world. Resurgent religion and world politics (Washington D.C., 1999). 
between medicine and religion, that is less influenced by the nineteenth century's premises of medical historiography. Other circumstances, such as some regions, e.g. in the most Western part of Germany, where the vast majority of hospitals are run by the churches, or the influence of the churches worldwide in the bioethical discourse, add further motivations to focus on the role of religion and especially Christianity in modern health care. A return, however, to the classical studies of medical historians on church and medicine would certainly not be in line with the more recent ways of writing history. For the earlier authors, including prominent scholars like Paul Diepgen ${ }^{4}$ and Paul Delaunay ${ }^{5}$, took the existence of two distinct entities - of medicine, represented by the medical profession, on the one side and religion as embodied by the church on the other side - for granted. Their question was how the two supposed realms were intertwined, with regard to ideology, institutions and persons.

Since meanwhile in contrast to this rather static view, more anthropological, functionalist and social constructivist approaches have influenced our view of historical development the borders between medicine and religion are no longer given by nature or as an obvious distinction, but are the result of social processes. One type of such processes is the increasing functional differentiation. Following this idea of functional systems in society concentrating more and more on a central binary code, such as "diseased - not diseased" in medicine - an idea prepared by Talcott Parsons in the Anglophone world and influential mainly in Germanspeaking countries by the systems theory of Niklas Luhmann ${ }^{6}$ - not only relations between medicine and religion, but primarily their continuing separation by functional differentiation should become a major subject of historians. On the other, the anthropological side which considers more the individual than social systems, concepts of cultural identity or mentality might explain why despite biomedicine's pledge of scientific objectivity and proof other ways of healing and looking on health and diseases have not disappeared completely.

Due to this double interest in social systems and mentalities the establishment of a social history of medicine should and indeed does increase an interest in the dialectic processes of secularisation in medicine. Secularisation has the double meaning of the more political and economic separation of state and church including expropriation of ecclesiastic institutions on the one side and of the more social and cultural loss of influence of the church on society and its functional systems on the

4 Paul Diepgen, Über den Einfluß der autoritativen Theologie auf die Medizin des Mittelalters. Abhandlungen der Geistes- und Sozialwissenschaftlichen Klasse der Akademie der Wissenschaften und der Literatur 1958, Nr. 1 (Wiesbaden, 1958).

5 Paul Delaunay, La Medecine et L'Eglise (Paris, 1948).

6 For medicine and religion cf. Niklas Luhmann, "Der medizinische Code", in N. Luhmann, Soziologische Aufklärung, vol 5 (Opladen 1990), pp. 183-195; Funktion der Religion (Frankfurt/M., 1982). 
other side. Both developments have their noticeable impact on health care. For their study the period around 1800 during which the term "secularization" originates offers vast materials and examples.

Following Luhmann's example, the sketch given here will not focus on the general population, but on professional groups, as the relevant processes are often more obvious in those who devote their whole lives to the functional systems. Therefore this study will analyse the three groups of doctors with their academic medicine, priests in their medical tasks and nuns working as nursing sisters in hospitals. Of course, such a framework drawn from the existing more general studies on medical and religious institutions invites further micro- and comparative studies.

This analysis is done on the particular situation in the German West during the time immediately before and after the French revolution and during the following restoration period. It focuses on the professional academic and health care institutions in the Catholic West of Germany, mainly the territories of the three politically most important archbishoprics of Cologne, Trier and Mainz, located along the middle and lower river Rhine. Their Prince Archbishops were at the beginning of the era under investigation simultaneously three of the originally seven Electors of the German emperor, and also rulers of other territories, among which is most notable Cologne's suffragan diocese Münster. After the Napoleonic wars most of these territories became provinces of Protestant Prussia.

\section{Physicians: Academic Medicine and Church Authorities}

During the second half of the eighteenth century, Catholic ecclesiastical institutions in Germany were divided concerning their attitudes towards recent changes in academic doctrines and the teaching of medicine, although generally a strong tendency for enlightenment ideas became dominant. At the universities of Catholic territories the philosophical and theological faculties were run by the Jesuits until the dissolution of their order by Pope Clemens XIV in 1773, whereas the faculties of law and medicine tended to be dominated by lay-persons who were generally more in favour of the enlightenment. However, in several of these universities, especially at the three old archiepiscopal seats in Cologne, Trier and Mainz, the medical faculties were in a state deplored by many contemporaries. ${ }^{8}$ They lacked books, funds,

7 The study was part of the preparation of a larger interdisciplinary research project on the nineteenth century ideological and institutional roots of German Catholicism's engagement in health care and bioethics, enabled by a grant from the Deutsche Forschungsgemeinschaft.

8 Hannemarie Wolff, Die Medizinische Fakultät der Kurfürstlichen Akademie und Universität zu Bonn (1777-1798). Ein Beitrag zur Geschichte des Medizinalwesens im Erzstift Köln (Ph. D. thesis Bonn, 1940), pp. 10-13. 
dedicated professors and therefore keen students who preferred Protestant universities in North-eastern Germany or Catholic universities in Vienna and France.

This situation of West German universities - not only in Catholic regions, for the Protestant university of Duisburg was in a similar state - given, several princes of larger territories opened academies for the education of their subjects, that were meant to be more in line with the interests of enlightened absolutism " than the existing universities with their often medieval or scholastic traditions. In those territories, where the enlightened prince was a member of the Catholic clergy, this meant a certain tension within religious control of medicine. E.g. in the territories of the Archbishops of Cologne, i.e. the archdiocese of Cologne and the diocese of Münster, there was a coexistence of the medieval university in Cologne dominated by the Catholic clergy and the new "Prince Electoral" ("Kurfürstliche") Academy or University of Cologne's Catholic Archbishop in Bonn and Münster. ${ }^{10}$ This opposition was intended by the founders and clearly seen by contemporaries. The curator of the new university in Bonn praised its recent foundation by the Archbishop of Cologne as "the greatest damage to the clergy in Cologne, but the greatest advantage to his territory". ${ }^{11}$

Whereas the traditional university was rather meant to educate future representatives of scholarship and the professions, the princes' - secular as well as ecclesiastic princes' - new academies and universities were designed to train servants of the state or its sovereign. Therefore the latter showed far more interest in "medicinische Policey", medical police or policy, the precursor of public health. More than in the older universities, the new medical faculties were at the same time the medical colleges and the medical councils regulating professional affairs for all health practitioners as well as public health. Professors were regularly detached to commissions enquiring in outbreaks of epidemics.

At the medical faculty of Bonn, all the professors could be counted among those members of the medical profession openly propagating enlightenment ideas. The first professor Kauhlen who after giving up his education for the Catholic priesthood and a degree in law at the University of Cologne had pursued his medical studies at the Calvinistic university of Duisburg and the Lutheran university of Strasbourg was already a locally established medical doctor at the time of the faculty's foundation, joined under the name "Tassilo" the free-mason order of the

9 On the relationship between enlightenment and medical reform cf. Wolfram Kaiser and Arina Völker, "Aufklärung und Philanthropismus", Medizinhistorisches Journal, 26 (1991), 283-299.

10 During the rule of the Prince Elector Archbishop of Cologne Max Friedrich (17081784) the Academy in Bonn was founded in 1777 and the Vice-University in Münster in 1780, under his successor Prince Elector Archbishop Max Franz (1784-1794) the Academy in Bonn was elevated to University in 1786.

11 Franz Wilhelm von Spiegel, quoted in D. Höroldt, ed., Geschichte der Stadt Bonn, vol 3 (Bonn, 1989), p. 316. 
Illuminati and published as an open opponent of church influence on science. ${ }^{12}$ The other three Bonn professors of medicine were appointed rather as intellectuals, i.e. theoretically minded researchers, from outside the archbishop's territory: de Gynetti $^{13}$, Rougement ${ }^{14}$ and Wurzer ${ }^{15}$. They adhered to versions of vitalism, combining the moderate iatromechanism of Hermann Boerhave, the animism of Georg Ernst Stahl and the theories of Albrecht von Haller on irritability and sensibility. These modern doctrines were regarded as results of the enlightenment and met opposition from conservative Christian circles as "materialism", although, of course, much of these doctrines came from a Pietistic background. These newly appointed medical professors saw themselves as opponents against old-fashioned traditions in medicine that according to their opinion were often related to religion. Thus in a public speech while still being the professor Primarius of the old medical faculty in Cologne, de Gynetti, like Kauhlen once destined for the priesthood and already recipient of the lower church orders, mocked Cologne's previous despise of scientific discoveries such as Harvey's on the circulatory system and advocated the dissection of corpses for scientific purposes against common prejudice. ${ }^{16}$ As his obituary notice of 1804 mentions "duty of religion" before "beneficence and morality" in characterising him, he has, however, certainly not been an outspoken freethinker.

The medical faculty at Münster ${ }^{17}$, advised by the Protestant physician Christoph Ludwig Hoffmann ${ }^{18}$, took a rather pragmatic and experience-oriented approach and preferred to choose its professors from the Münsteranian territory (Lüders ${ }^{19}$,

12 Franz Wilhelm Kauhlen (1750-1793), cf. Braubach, Hochschule, pp. 168-171; Richard van Dülmen, Der Geheimbund der Illuminaten. Darstellung, Analyse, Dokumentation (Stuttgart, 1975), pp. 439-453.

13 Peter Wilhelm Joseph de Gynetti (1735-1804), cf. Braubach, Hochschule, pp. 171-172; Everhard Hendrichs, "Peter Wilhelm Joseph de Gynetti", Nachrichtenblatt des Vereins Alter Münstereifeler, 54 (1979), 3-7; Hannemarie Wolff, Die Medizinische Fakultät der Kurfürstlichen Akademie und Universität zu Bonn (1777-1798). Ein Beitrag zur Geschichte des Medizinalwesens im Erzstift Köln (Ph. D. thesis Bonn, 1940), pp. 52-53.

14 Joseph Claudius Rougemont (1756-1818), cf. Wolff, Fakultät, p. 60.

15 Ferdinand Wurzer (1765-1844), cf. Wolff, Fakultät, p. 85.

16 Peter Wilhelm de Gynetti, Programma anatomicum (Köln, ca. 1775); cf. Friedrich Moritz, Aus der medizinischen Fakultät der alten Universität, in H. Graven, ed., Festschrift zur Erinnerung an die Gründung der alten Universität Köln im Jahre 1388 (Köln, 1938) pp. 237-287, here pp. 276-277.

17 Cf. Gisela Böger, Zur Geschichte der ersten Medizinischen Fakultät (1773-1818) und der Chirurgenschule (1821-1849) in Münster (M.D. thesis Münster, 1956).

18 Cf. Maria Weidekamp, Der Kurfürstliche Leibarzt Christoph Ludwig Hoffmann. Sein Leben und sein Wirken im Hochstift Münster von 1764-1785 (M.D. thesis Münster, 1936/Berlin, 1937); Broman, Transformation, pp. 55-57.

19 Bernhard Lüders (+1807), cf. Richard Toellner, "Medizin in Münster", in H. Dollinger, ed., Die Universität Münster (Münster, 1980), p. 288. 
Druffel $^{20}$, Bodde $^{21}$, Roling, Wernekinck ${ }^{22}$ ), three of them without a doctorate. Thus both the new institutions founded under the rule of the Archbishop Prince Electors of Cologne, in Bonn and in Münster, can be classified as theoretical or practical centres of the Enlightenment. When Hoffmann was also called by the Archbishop and Prince Elector of Mainz to introduce medical reform in this principality he failed, obviously because of the resistance from the old medical faculty there. ${ }^{23}$

The new academic foundations together with the old institutions were dissolved during the French occupation of the Rhineland beginning in 1792, the following political secularization and the Prussian reforms. When also thereby all the bishops had lost their secular power, a remarkable change could be observed in their medical policy, too. As princes they favoured public health and therefore even fought some religious traditions regarded as detrimental for health such as baptism of the newborns in cold churches or various forms of religious healing. As mere pastoral bishops their responsibility and interest was different. Caused by their negative experiences with the revolution which was regarded as a result of the enlightenment most representatives of the church turned away from many modernised institutions and sought to revive church traditions. Thus pilgrimage and the interest in miracles of healing as well as other physical phenomena increased. There are obvious personal and intellectual connections between ecclesiastical restoration, Schelling's natural philosophy so influential on medicine, the medical discussions on Mesmerism or animal magnetism and the increasing number of devoted women demonstrating religious ecstasy, bleeding stigmata and fasting, especially in Catholic Bavaria. $^{24}$

20 Franz Ferdinand (von) Druffel (1763-1857), cf. Klaus Böger, Aus dem Leben und Wirken des Medizinalrates und Professors der ersten Medizinischen Fakultät zu Münster Franz Ferdinand von Druffel (M.D. thesis Münster, 1961); Helga Jagemann, Franz Ferdinand von Druffels (17631857) "Pathologische Therapeutische Vorlesungen" (M.D. thesis Münster, 1964).

21 Johann Bernhard Bodde, famous for his „enlightened“ writings on the case of the stigmatised nun Anna Katharina Emmerick (s. below): Johann Bernhard Bodde, Bericht über die Erscheinungen bey der A. K. Emmerich, Chorschwester des aufgehobenen Klosters Agnetenberg in Dülmen von dem Herrn Medizinal Rath Bodde mit Entgegnungen von B. A. B. Rensing Dech. in Dülmen (Dorsten, 1818); Sendschreiben an den Herrn Rensing, Dechant und Pfarrer zu Dülmen, worin derselbe einer Theilnahme an der Erkünstelung der Wundmaale der Jungfer Emmerich nicht beschuldigt, das Wundersame der Wundmaale aber standhaft verneint wird (Hamm, 1819).

22 Franz Wernekinck (1764-1839), cf. Hans Kaja, Franz Wernekinck, Arzt und Botaniker (1764-1839) und seine Pflanzenbilder aus dem Münsterland (Münster, 1995).

23 Cf. Broman, Transformation, pp. 57-59.

24 Cf. Bernhard Gissibl, "Zeichen der Zeit? Wunderheilungen, Visionen und ekstatische Frömmigkeit im bayerischen Vormärz", in N. Freytag and D. Sawicki, eds., Wunderwelten. Religiöse Ekstase und Magie in der Moderne (München, 2006), 83-114. 
In the West of Germany an early and well known case ${ }^{25}$ that was also quite influential for the development of health care and characteristic for the internal conflicts of physicians being torn between enlightenment medicine and religion is the stigmatised "Nun of Dülmen" in the dioceses of Münster, Anna Katharina Emmerick. When she got the bleeding wounds in hand and feet, she was allegedly living without eating after her monastery had been dissolved as a consequence of the secularisation. Her literary memorial was written by the famous romantic poet Clemens Brentano. More than 30 physicians visited her in order to check the truth of the reports. The medical world was divided on this topic.

The immediate consequences in the field of health care that her miraculous suffering had for some of her visitors and friends were remarkable. At least two young physicians changed their life after their visits to Anna Katharina. The medical doctor Franz Wesener turned from the enlightened world view to traditional Catholic positions, recorded the nun's sufferings meticulously and thereby encountered strong resistance and open mockery from the medical establishment. ${ }^{26}$ Clemens Brentano's brother Christian, also a physician, changed his interest to theology and became a writer. ${ }^{27}$

Several Protestant visitors and friends converted to Catholicism. They and other impressed visitors began activities for the sick. The most prominent among them was Friedrich Leopold Graf zu Stolberg who donated the means for the work of the Sisters of St. Clement, mainly engaged in nursing, who were founded by the Vicar General Clemens August von Droste zu Vischering at that time. ${ }^{28}$ The daughter of a Protestant pastor Luise Hensel devoted her life to the poor and became a pioneer in female education. ${ }^{29}$ Among her pupils were two later beatified founders of religious congregations also devoted to nursing, Franziska Schervier and Pauline

25 For her biography, visitors and influence cf. Clemens Engling, Unbequem und ungewöhnlich: Anna Katharina Emmerick - historisch und theologisch neu entdeckt (Würzburg, 2005); August Hölscher, Emmerich oder Emmerick? Gutachten d. Historikers August Hölscher, bearb. im Auftr. d. Heimat-u. Verkehrsvereins Dülmen (Dülmen, 1931); Peter Groth, Die stigmatisierte Nonne Anna Katharina Emmerick 1774-1824. Eine Krankengeschichte im Zeitalter der Romantik - zwischen preußischer Staatsraison und 'katholischer Erneuerung' (unpublished dissertation, 1994).

26 Cf. Wilhelm Hümpfner, ed., Tagebuch des Dr med. Franz Wilhelm Wesener über die Augustinerin Anna Katharina Emmerick (Würzburg, 1926).

27 Cf. Alexander Loichinger, "Sailer, Diepenbrock, Christian und Clemens Brentano", Münchener Theologische Zeitschrift, 52 (2001), 304-322.

28 Manfred Weitlauff, "Die Konversion des Grafen Friedrich Leopold zu Stolberg zur katholischen Kirche (1800) und seine 'Geschichte der Religion Jesu Christi' (1806-1818)", in M. Weitlauff, ed., Für euch Bischof, mit euch Christ. Festschrift Friedrich Kardinal Wetter (St. Ottilien, 1998), pp. 271-321.

29 1798-1876, cf. Barbara Stambolis, Luise Hensel (1798-1876). Frauenleben in historischen Umbruchszeiten (Köln, 1999). 
von Mallinckrodt. ${ }^{30}$ Apollonia Diepenbrock, also a friend of Hensel, left her homeland in order to serve the sick and poor in Koblenz and Regensburg. ${ }^{31} \mathrm{Her}$ brother Melchior (von) Diepenbrock, a junior military officer dissatisfied with his service, became a priest and finally prince bishop of Breslau where he was active in founding hospitals, too. ${ }^{32}$

This revival of nursing congregations and Christian hospitals will be treated separately later, but the romantic regret of what had been lost in comparison to earlier times reached also academic medicine, mainly in the highly diverse variations of natural philosophy. The textbooks of medical history tend to describe "romantic medicine" as characterised by "a special attitude of reverence for God, nature and man. ${ }^{33}$ As has been demonstrated by medical historians extensively, romantic medicine was by no means a monolithic and mainly backwards oriented endeavour. $^{34}$ Many approaches of its representatives have been crucial for the

30 Cf. Relinde Meiwes, "Weibliche Lebenswege im 19. Jahrhundert. Das Beispiel der Kongregationsgründerinnen Franziska Schervier und Pauline von Mallinckrodt", in B. Hermans, ed., Lebensläufe im Sozialkatholizismus des Ruhrgebiets. Historische Fachtagungen (Essen, 2003), pp. 75-85.

31 1799-1880, cf. Ursula Finken, “Apollonia Diepenbrock (1799-1880). Ein Leben für die Armen", in W. Becker, ed., Staat, Kultur, Politik. Beiträge zur Geschichte Bayerns und des Katholizismus. Festschrift Dieter Albrecht (Kallmünz, 1992), pp. 237-247; Ulrike Philipp, “'Unseren lieben Heiland in seinen Kranken zu pflegen.' Die sozialfürsorgerischen Tätigkeiten Apolonia Diepenbrocks in Regensburg (1834-1880)", Beiträge zur Geschichte des Bistums Regensburg, 37 (2003), 197-291.

32 1798-1853, cf. Alexander Loichinger, Melchior Diepenbrock. Seine Jugend und sein Wirken im Bistum Regensburg (1798-1845) (Regensburg, 1988).

33 Karl E. Rothschuh, Konzepte der Medizin in Vergangenheit und Gegenwart (Stuttgart, 1978) p. 387.

34 Cf. Karl Eduard Rothschuh, "Deutsche Medizin im Zeitalter der Romantik", in L. Hasler, ed., Schelling. Seine Bedeutung für eine Philosophie der Natur und Geschichte (Stuttgart, 1981), pp. 145-152. For previous research on romantic medicine in general cf. Dietrich von Engelhardt, "Bibliographie der Sekundärliteratur zur romantischen Naturforschung und Medizin 1950-1975“, in R. Brinkmann, ed., Romantik in Deutschland (Stuttgart, 1978), pp. 307-330. After medical historians around 1900 had described romantic medicine and natural philosophy as a culde-sac of medical progress, a view still influential in some textbooks, the higher esteem of Schelling's philosophy and more intense study of the sources demonstrated their importance for the following natural sciences in medicine. This emphatic judgement beginns with such early remarks as Karl Schmiz, Die medizinische Fakultät der Universität Bonn 1818-1918. Ein Beitrag zur Geschichte der Medizin (Bonn, 1920), pp. 3, and is still dominant in the resolutely secularizing interpretations after the 1960s such as Nelly Tsouyopoulos, Andreas Röschlaub und die romantische Medizin (Stuttgart, 1982). For more recent studies cf. Hans-Uwe Lammel, Nosologische und therapeutische Konzeptionen in der romantischen Medizin (Husum, 1990); Urban Wiesing, Kunst oder Wissenschaft? Konzeptionen der Medizin in der deutschen Romantik (Stuttgart-Bad Cannstatt, 1995); for a rather limited description cf. Werner E. Gerabek, Friedrich Wilhelm Joseph Schelling und die Medizin der Romantik (Frankfurt/M., 1995). 
development of medical research, especially in physiology and psychotherapy. ${ }^{35}$ These approaches, however, shared the conviction that several medical ideas of the preceding decades were fundamentally flawed by a too narrow, analytical focus, especially when compared to the synthetic approach in the alleged Golden age of ancient or Hippocratic medicine. ${ }^{36}$ This turn made medicine again also open to religious, predominantly mystical speculation. ${ }^{37}$ Recent historiographic studies, however, in reaction to the earlier medical historians' characterisation of this period as reactionary and confused, ${ }^{38}$ rarely describe the obvious affection of romantic medicine to religion. One reason for this might be that the Christian churches indeed had their own problems with Schelling's natural philosophy and with the natural philosophical, e.g. Mesmerist explanation of miracles. Nevertheless, it remains remarkable that after 1800 several prominent medical academics showed similar tendencies of moving from medical practice to philosophy, from enlightenment to Romanticism, and some of them proceeded to open religion. A role model was the famous writer Joseph Görres, ${ }^{39}$ coming from the Rhineland, but moving to Munich later, who had among other interests studied, taught and occasionally practised medicine, and turned from an adherent of the French revolution and a natural philosophical version of medical materialism ${ }^{40}$ to a Catholic mystic. ${ }^{41}$ A similar biography for the territories considered here is Karl

35 Cf. Nelly Tsouyopoulos, "Schellings Naturphilosophie: Sünde oder Inspiration für den Reformer der Physiologie Johannes Müller?”, in M. Hagner, ed., Johannes Müller und die Philosophie (Berlin, 1992), pp. 65-83; Brigitte Lohff, Die Suche nach der Wissenschaftlichkeit der Physiologie in der Zeit der Romantik. Ein Beitrag zur Erkenntnisphilosophie der Medizin (Stuttgart, 1990), and "Johannes Müller und die Geschichte der Physiologie", in H. Schott, ed., Medizin, Romantik und Naturforschung. Bonn im Spiegel des 19. Jahrhunderts (Bonn, 1993), pp. 37-58; Henry F. Ellenberger, Die Entdeckung des Unbewussten (Bern, 1973), pp. 281-304.

36 Thomas H. Broman, The transformation of German academic medicine, 1750-1820 (Cambridge, 1996) p. 141, especially footnote 33.

37 For the "turn of scientific activity to the religious" cf. Brigitte Lohff, Die Suche nach der Wissenschaftlichkeit der Physiologie in der Zeit der Romantik. Ein Beitrag zur Erkenntnisphilosophie der Medizin (Stuttgart, 1990) p. 32, especially footnote 14; for relations between Romantic medicine and religious ideas cf. Volker Roelcke, "Kabbala und Medizin der Romantik", in E. Goodman-Thau, G. Mattenklott and C. Schulte, eds., Kabbala und Romantik (Tübingen 1994), pp. 119-142, especially pp. 128-129.

38 Cf. Wiesing, Kunst, pp. 28-43, especially p. 31.

39 1776-1848, cf. Jon Vanden Heuvel, A German life in the age of revolution. Joseph Görres, 1776-1848 (Washington, D.C., 2001); for his medical or natural philosophical views cf. Broman, Transformation, pp. 95-96.

40 Cf. Joseph Görres, Aphorismen über die Organomie (Koblenz, 1803), e.g. the explanation of brain and psyche/soul pp. 286-313.

41 Cf. Joseph Görres, Christliche Mystik, 4 vols (1836-1842). 
Joseph Hieronymus Windischmann. ${ }^{42}$ He had been earlier the author of an attempt to explain man and medicine in a highly materialistic approach, aiming at a "mechanics of nature" ${ }^{\text {"3 }}$ and even admitted to Reil's "Archiv für die Physiologie" in $1800^{44}$ which still built a stronghold against natural philosophy at that time. ${ }^{45}$ Then he was the court physician of the enlightened Archbishop of Mainz, Karl Theodor von Dalberg and professor of history and philosophy at Dalberg's first place of exile in Aschaffenburg. After becoming a professor in the philosophical and the medical faculty at the new Bonn University he wrote in 1823 "About something which is necessary for medicine. An attempt to unify this art with Christian philosophy". ${ }^{46}$ As the title indicates, the articles, a year later published as a book, propose a mystical approach to medicine where diseases are the consequences of general disorder, i.e. sin, and the task of medical research is conceived very encompassing: "The more a science refers to the human being and his inner nature and hidden ailments, the less it can be treated without religion" "Wi . Windischmann explicitly expressed his dissatisfaction with a medicine confined to the "mechanics of nature" and the "jail of materialism". ${ }^{48} \mathrm{He}$ now saw natural remedies as part of a harmonious creation integrated at the bottom of a hierarchy for means to ensure human salvation ("Heil") - and ecclesiastical rites such as prayer and blessed water, the sacraments and exorcism forming the top.

Quoting Windischmann means returning to the history of universities, for he was not isolated by such ideas in the medical faculty. In that region of Western Germany that before the French occupation had got the mentioned six medical faculties of universities (Bonn, Cologne, Trier, Mainz, Münster and the Prussian, thus Protestant University of Duisburg ${ }^{49}$ ) there was now only the one in Bonn,

42 1775-1839, cf. Adolf Dyroff, Carl. Jos. Windischmann (1775-1839) und sein Kreis. Görres-Gesellschaft zur Pflege der Wissenschaft im katholischen Deutschland. Vereinsschrift 1916/1 (Köln, 1916); Gerabek, Schelling, pp. 256-262.

43 Versuch ueber die Medizin. Nebst einer Abhandlung über die sogenannte Heilkraft der Natur (Ulm, 1797), pp. 14 and 39.

44 "Über den einzig möglichen und einzig richtigen Gesichtspunkt aller Naturforschung. Nebst der Ankündigung einer Schrift über die Mechanik der Natur”, Archiv für die Physiologie, 4 (1800), 290-305.

45 Reinhard Mocek, Johann Christian Reil (1759-1813). Das Problem des Übergangs von der Spätaufklärung zur Romantik in Biologie und Medizin in Deutschland (Frankfurt, 1995), p. 137.

46 "Ueber etwas, das der Heilkunst Noth thut. Ein Versuch zur Vereinigung dieser Kunst mit der christlichen Philosophie", Nasse's Zeitschrift für Anthropologie, III and IV (1823).

47 Karl Joseph Hieronymus Windischmann, Ueber etwas, das der Heilkunst Noth thut. Ein Versuch zur Vereinigung dieser Kunst mit der christlichen Philosophie (Leipzig, 1824), p. 150.

48 Ibid., pp. 68 and 70.

49 Gernot Born and Frank Kopatschek, Die alte Universität Duisburg 1655-1818 (Duisburg, 1992); Günter von Roden, Die Universität Duisburg. Duisburger Forschungen, 12 (Duisburg, 1968); Walter Ring, Die Geschichte der Universität Duisburg (Duisburg, 1920); Hans-Ulrich 
being part of the in 1818 newly founded Prussian university. ${ }^{50}$ The professors of this new faculty ${ }^{51}$, half of them Protestant, were influenced by the general development during this era and therefore at least initially largely inclined to natural philosophy and Mesmerism. ${ }^{52}$ Against the assumption that the Prussian Chancellor Hardenberg's physician Koreff, a professed Mesmerist, had decisively influenced this composition of the Bonn medical faculty it has been demonstrated that Koreff mostly failed in his proposals for adherents of Schelling or Mesmer as candidates for chairs in Bonn. ${ }^{53}$ Nevertheless, the only obvious exception from the general tendency towards natural philosophy was the staunch opponent of Mesmerism, the professor of Anatomy August Franz Josef Karl Mayer, ${ }^{54}$ who had studied at the Lutheran University of Tübingen and had formerly taught in Calvinistic Bern. Among the other professors who beside their special interests also studied Mesmerism and natural philosophy were three very famous names: the clinician Christian Friedrich Nasse $^{55}$, the surgeon and ophthalmologist Philipp Franz von Walther ${ }^{56}$ and the botanist Christian Gottfried Daniel Nees von Esenbeck. ${ }^{57}$ Nasse and von Walther, however freed themselves from animal magnetism and natural philosophy later in their lives. ${ }^{58}$ Among the less well known Bonn professors were some remaining loyal to natural philosophy like the new university's first medical professor Johann

Müller, Die medizinischen Promotionen an der Universität Duisburg 1655-1817. Medizin im Museum, Beiheft 2 (Essen, 2004).

50 As the time gap between the actual end of the medieval and princely universities and the official foundation of new medical teaching institutions by the Prussian state was mostly at least more than twenty years (and some like in Mainz or Cologne were only re-founded in the twentieth century) there was hardly any continuity in personnel. The remarkable exception was the new school of surgeons in Münster which was founded in 1821 three years after the dissolution of the old university: Apart from Druffel all the previous professors (Bodde, Roling and Wernekinck) as well as Drs. Busch and Haindorf remained lecturers, according to Richard Toellner, "Medizin", p. 292.

51 Christian Renger, Die Gründung und Einrichtung der Universität Bonn und die Berufungspolitik des Kultusministers Altenstein (Bonn, 1982).

52 Schmiz, Fakultät, pp. 1-7.

53 Cf. Renger, Gründung, pp. 162-184.

54 1787-1865, cf. Johannes Dietrich Meyer, August Franz Josef Carl Mayer. Leben und Werk (Diss. Bonn, 1966); cf. Renger, Gründung, pp. 166-167.

55 Cf. Heinrich Schipperges, "Christian Friedrich Nasse 1778-1851", in Bonner Gelehrte. Beiträge zur Geschichte der Wissenschaften in Bonn. Medizin (Bonn, 1992), pp. 23-35.

56 Cf. Erich Freiherr von Redwitz, "Philipp Franz von Walther. 1782-1849", in Gelehrte, pp. 36-40. For his interest in natural philosophy cf. Wiesing, Kunst, pp. 244-255; Lohff, Suche, p. 122.

57 1776-1858, cf. Dietrich von Engelhardt, ed., Christian Gottfried Nees von Esenbeck. Politik und Naturwissenschaften in der ersten Hälfte des 19. Jahrhunderts (Stuttgart, 2004).

58 Cf. Redwitz, "Walther", p. 38; Renger, Gründung, p. 181; Nasse gave up his function as co-editor of the Archiv für thierischen Magnetismus in 1822. 
Christian Friedrich Harless, ${ }^{59}$ the pharmacologist Ernst Bischoff ${ }^{60}$ and the ardent proponent of Mesmerism Joseph Ennemoser. ${ }^{61}$ After becoming full professor at Bonn University in 1827, Ennemoser made his research programme explicit the next year:

If man in general is the object of medical studies, then everything of man belongs to their area; and whoever reflects on the essence (Wesen) of the human being seriously cannot evade the religious perspective, yes, he even will have to deal with it primarily. ${ }^{62}$

Accordingly, like Görres in the influential work of the years in his famous circle in Munich, he discussed later in his life such religious and physical phenomena as the above-mentioned Anna Katharina Emmerick extensively. ${ }^{63}$

Thus the seemingly paradoxical situation resulted that the dominating teaching at the former archbishop's university had been openly connected to ideas of enlightenment and sometimes even materialism whereas the new university founded by the secular and Protestant Prussian king was a refuge for adherents of romantic natural philosophy with its links to Christian and especially Catholic mysticism.

\section{Priests and Health Care: The Development of Pastoral Medicine}

The common view as canonised in classical textbooks of medical and ecclesiastical history used to be that medical practice by priests ceased with the prohibitions by popes, synods and councils in the twelfth and beginning thirteenth century. Several medical historians, however, pointed out well-known priests as court physicians of popes and bishops in later times and the continuing medical practice of the lower clergy, often in direct extension of their spiritual power. It has been demonstrated for Dutch and English territories how extensively in the Early modern period

59 Cf. Charlotte Triebel-Schubert, "Johann Christian Friedrich Harless 1773-1853", in: Gelehrte, pp. 13-22. $41-43$.

60 Cf. Gernoth Rath, "Christian Heinrich Ernst Bischoff. 1781-1861", in Gelehrte, pp.

61 Cf. Jakob Bremm, Der Tiroler Joseph Ennemoser, 1787-1854, ein Lehrer des tierischen Magnetismus und vergessener Vorkämpfer des entwicklungsgeschichtlichen Denkens in der Medizin, Professor der Medizin in Bonn a. Rh. Ein Beitrag zur Kenntnis des sog. tierischen Magnetismus, zur Geschichte der Freiheitskriege und der Medizinischen Fakultät in Bonn (Jena, 1930).

62 Josef Ennemoser, Ueber die Aufgabe der anthropologischen Forschung und das Wesen des menschlichen Geistes (Bonn, 1828) p. V.

63 Josef Ennemoser, Der Magnetismus im Verhältnisse zur Natur und Religion (Stuttgart, 1842) p. 154-157. 
especially Catholic priests applied rituals for the healing of physical ailments whereas Protestants theology more successfully forced the clergy to refrain from such a magical blurring of borders. ${ }^{64}$ As the peasants did not so much distinguish between natural and supernatural means they demanded both from their priests as the only educated men in their communities. Thus medical activities by priests, like the famous exorcist Father Joseph Gassner in Bavaria, were still common when the enlightenment produced the idea of popularising medicine, including actively spreading the achievements of medicine to people who could not afford or reach an academic physician. This idea started with medical books addressed to those nondoctors who could read, i.e. the gentry, the teachers and especially the clergy whose professional obligation to charity and knowledge of the people made them especially suitable for rendering services in health care. The famous examples of these books are written by Philibert Guibert in the seventeenth century and - the probably best-known of all times - Samuel Auguste Tissot in the eighteenth century. ${ }^{65}$

Based on these examples how educated people without medical training could help the sick the idea of employing priests for matters of health was often taken up in the decades around $1800 .{ }^{66}$ Famous doctors such as Christoph Wilhelm Hufeland $^{67}$ and Johann Peter Frank ${ }^{68}$ became involved in this enterprise. ${ }^{69}$ As the

64 Hans de Waadt, "Chasing demons and curing mortals: the medical practice of clerics in the Netherlands", in H. Marland and M. Pelling, eds., The task of healing. Medicine, religion and gender in England and the Netherlands (Rotterdam, 1996), pp. 171-203; David Harley, "James Hart of Northampton and the Calvinist Critique of Priest-Physicians: An unpublished Polemic of the early 1620s", Medical History, 42 (1998), 362-386.

65 Philibert Guibert, Le médicin charitable (1624), in 1632 supplemented by L'apoticaire charitable, resulting in the combined volume Oevres charitables; Samuel Auguste Tissot, Avis au peuple sur sa santé, vol 1 (Paris, ${ }^{2} 1763$ ), pp. xliii-xliv.

66 Cf. Broman, Transformation, pp. 107-108.

67 1762-1836, Christoph Wilhelm Hufeland, "Medizinische Praxis der Landgeistlichen", Journal der practischen Heilkunde, 29/5 (1809), 1-10.

68 1745-1821, Johann Peter Frank, Academische Rede über Priester-Aerzte (1803); System einer vollständigen medicinischen Polizey, VI (1817).

69 Cf. Claudia Huerkamp, Der Aufstieg der Ärzte im 19. Jahrhundert. Vom gelehrten Stand zum professionellen Experten. Das Beispiel Preußens (Göttingen, 1985), p. 43; as examples for the passionate debate cf. Christian Gottfried Gruner, "Laßt die Aerzte absterben, und die Pfarrer an die Stelle treten", Almanach für Aerzte und Nichtaerzte auf das Jahr 1787 (Jena, 1787), 188-194 [an attack on Bahrdt's proposal, Tissot's book and medical education for theologians]; Paulus Usteri, Grundlage medicinisch-anthropologischer Vorlesungen für Nichtärzte (Zürich, 1791); J. Krause, Der medicinische Landpfarrer, oder kurzgefaßte medicinische Abhandlung und Heilart derjenigen Krankheiten, welche am meisten auf dem Lande vorkommen. Allen Herren Seelsorgern und Wundärzten in den Orten, in welchen keine Aerzte wohnen, zu ihrem Gebrauche und Wiedergenesung der Kranken redlichst gewidmet von J. Krause, der W. und A. D., Oberamtsarzt zu Neustadt an der Hardt (Schweinfurth, 1794), reviewed Medicinisch-chirurgische Zeitschrift, Nr. 35 of 1 May (1794), 157-160. 
absolutist state was more interested in health than in medical care, priests were expected to assist in public health, too. Medical historians have collected examples that priests should persuade their parishioners to have their children vaccinated, and in the territory of Hessen-Darmstadt a thorough knowledge of Tissot's book was even precondition for gaining a living as pastor. ${ }^{70}$ Priests were also asked to discourage magical or unhealthy practices and to recommend, even assist an academic doctor.

One result of this participation of the clergy in medical tasks was a new genre of books which especially addressed priests. Titled "pastoral medicine", these publications were written by physicians in collaboration with priests and meant to provide the medical knowledge necessary for pastoral work. What was regarded as a pastor's job, however, was subjected to characteristic changes that have been analysed by pastoral theologians ${ }^{71}$ and are shown for the medical side here. To reduce the development to the relevant traits it can be said that in the early writings the enlightenment idea of mobilizing more resources for increasing public utility was dominant. The question was how church and priest might assist in medicine and public health - and not so much the other way round. Priests were to be trained in knowing, preventing and treating the most common diseases. In accord with this humanitarian approach, there was hardly any denominational polemic in the early publications. They centred on medicine, not religion.

Of course, there are exceptions from the general focus on medicine, such as the probably best known and most thoroughly written book of pastoral medicine in that time, Franz Xaver Mezler's "Ueber den Einfluss der Heilkunst auf die praktische Theologie. Ein Beytrag zur Pastoralmedicin". "Although in the subtitle of its first volume it claims to treat the influence of "Heilkunst", medicine, on "Sittlichkeit", morality, which is perhaps best understood as social and individual conduct of life, it does much more. It provides medical knowledge in its broadest meaning, mainly anthropology including natural history of man and psychology, and deals only rarely with medical care. With this provision of anthropological, psychological and medical knowledge necessary or at least helpful for qualified pastoral care Mezler already aims at the core interest of the later established discipline of pastoral medicine. During the period of restoration, pastoral medicine does no longer want to train assistant physicians, but wants to make medicine an assistant to pastoral care.

70 Robert Heller, "Priest-Doctors' as a Rural Health Service in the Age of Enlightenment”, Medical History, 20 (1976), 361-383; Robert Heller, “Johann Christian Reil's training scheme for medical auxiliaries", Medical History, 19 (1975), 321-332.

71 Cf. as the most comprehensive study Heinrich Pompey, Die Bedeutung der Medizin für die kirchliche Seelsorge im Selbstverständnis der sogenannten Pastoralmedizin. Eine bibliographischhistorische Untersuchung bis zur Mitte des 19. Jahrhunderts (Freiburg/Br., 1968).

72 In two volumes of 1794, second edition 1806 and third 1808. 
Moving from literary discourse to social reality this change is also demonstrable in church discipline. ${ }^{73}$ Whereas the priest in the immediate pre-revolutionary time was seldom punished by ecclesiastic authorities for medical practice this became more common when the bishops had to confine their power to spiritual tasks. Now priests were reprimanded and even suspended if medical practice on their part became known.

Thus it can be argued that the separation of the church from the state, for Catholic territories with their former prince bishops more obvious than for Protestant ones, made an end to the toleration and even recruitment of rural priests as assistant physicians. One of the most convincing points for this argument is the opposite observation in countries where the administrative separation between church and state was far less advanced, namely Lutheran and Orthodox monarchies. Already at the beginning of the nineteenth century Johann Peter Frank mentioned for Russia plans, even an Ukase from the Emperor, to train candidates for the priesthood in rural areas also in medicine. ${ }^{75}$ In Lutheran Sweden the parliament decided on funding a scheme for the medical training of theological students in 1810, and a medico-theological faculty was established at the University of Lund, formally existing until $1841 .^{76}$ So it was not so much the professionalisation of medicine or an increased availability of physicians in rural areas that decreased the medical activities of the clergy but the churches' withdrawal from duties in state and society in order to concentrate on their religious tasks. Thus political history seems to have perhaps more contributed to this development than the history of ideas or medicine itself. This might also explain why especially in areas with less social secularisation, that means with less separation between church and society such as Bavaria in Southern Germany, later in the century priests continued to be often consulted for health matters - despite and in the presence of medical doctors. $^{77}$

73 For the general turn from the enlightenment idea of "the priest as the people's teacher" to the new image of the "unworldly, sacred and spiritualised" clergy cf. Gissibl, "Zeichen der Zeit?”, pp. 97-99.

74 Georg May, "Die Aufrechterhaltung der Disziplin im Klerus”, in W. G. Rödel and R. E. Schwerdtfeger, eds., Zerfall und Wiederbeginn. Vom Bistum Mainz zum Erzbistum Mainz (1792/97-1830). Ein Vergleich. Festschrift Friedhelm Jürgensmeier. Beiträge zur Mainzer Kirchengeschichte, 7 (Würzburg, 2002), pp. 293-318.

75 Frank, System, VI, pp. 438-445.

76 Cf. Heinz Goerke, "Medizinische Ausbildung von theologischen Studenten an der Universität Lund von 1813 bis 1840", in H.-H. Euelner et al, eds., Medizingeschichte in unserer Zeit. Festschrift Edith Heischkel-Artelt (Stuttgart, 1971), pp. 352-358.

77 Cf. Michael Stolberg, "Alternative Medicine in Nineteenth-Century Bavaria", in R. Jütte, M. Eklöf and M. C. Nelson, eds., Historical aspects of unconventional medicine: approaches, concepts, case studies (Sheffield, 2001), pp. 147 and 153. 


\section{Nursing sisters: New Congregations and Hospitals}

The Catholic contribution to the development of nursing as a profession in general is a well known chapter in the history of nursing and medicine. ${ }^{78}$ Towards the end of the eighteenth century the new more clinically oriented, hospital-based type of academic medicine demanded qualified nursing which was widely missing at that time. Meeting this need, religious congregations followed the tradition of the well trained Sisters of Charity founded by Vincent de Paul in the seventeenth century. This tendency was supported by the policy of several enlightened catholic monarchs to dissolve monasteries without public utility, by which they understood activities in education or care for the poor and sick. Thus already before the French revolution Catholic religious congregations shifted towards more work in nursing.

After the dissolution of most monasteries by revolution, occupation and official secularization, that was equal to an existential crisis for many of the now former monks and nuns, the state's suppression of monastic life continued even after the end of the Napoleonic Wars and the Congress of Vienna. The only religious congregations that were allowed to have novices were again those devoted to health care and education, namely in Prussia the sisters of St. Ursula and St. Elisabeth and the Brethren of Charity. ${ }^{79}$ Thus the again increasing number of those who felt inclined to a life as sister or brother in a religious order was forced to enter nursing or teaching. Promoted by leading romantic authors such as the already mentioned Joseph Görres and Clemens Brentano ${ }^{80}$, the care for the sick was re-established as part of Catholic or - to be seen with the Protestant deaconesses of Theodor Fliedner - Christian identity.

The enormous increase of religious congregations living for and from nursing was made possible by the new hospitals founded in obviously all cities and towns. Members of religious orders also served in secular health care institutions, such as the new University hospitals, but their main interest was to work in Catholic hospitals and more and more even in their own hospitals. Catholic hospitals were certainly also a result of the attempt to strengthen Catholic identity in territories that were now ruled by Protestant monarchs and where therefore Catholic citizens tried to establish health care institutions independent from the state. An often imitated

78 Cf. Eduard Seidler and Karl-Heinz Leven, Geschichte der Medizin und der Krankenpflege (Stuttgart, ${ }^{7} 2003$ ), pp. 166-167.

79 Erwin Gatz, Kirche und Krankenpflege im 19. Jahrhundert. Katholische Bewegung und karitativer Aufbruch in den preußischen Provinzen Rheinland und Westfalen (München, 1971), p. 37.

80 Cf. Clemens Brentano, Die Barmherzigen Schwestern in Bezug auf Armen- und Krankenpflege (Koblenz, 1831; Mainz, ${ }^{2} 1852,{ }^{3} 1856$ ); Brentano's most important contact in the care for the poor and the sick was the already mentioned Apolonia Diepenbrock. 
model was the Johannes-Hospital in Bonn. ${ }^{81}$ In 1842 citizens of all denominations, led by the town mayor, founded a society for a citizens' hospital. When, however, the Catholic majority in the committee of this society wanted to call Catholic sisters of charity as nurses, the Protestant and Jewish members left the society and founded institutions of their own. Bishops of Catholic territories in Prussia supported the foundation of new Catholic hospitals actively, ${ }^{82}$ whereas in German territories with a Catholic monarch such as Bavaria the church's traditional influence on old and new hospitals did not make a similar wave of Catholic hospitals necessary.

\section{Conclusion}

The argument that there had been a certain move from the enlightenment idea of religion serving medicine (or to express it in analogy to the medieval relationship between theology and philosophy: "religio ancilla medicinae") to a romantic subordination of medicine under religion ("medicina ancilla religionis") in the majority Catholic regions of Western Germany was examined for three different groups of professionals. Although all of these groups, Catholic physicians, priests and nursing sisters in religious congregations, participated in the mental change from enthusiasm for public utility in the late enlightenment to the revival of devotion in the period of restoration, the practical consequences for each group were quite different. Whereas more women than ever before devoted their life to institutionalised nursing as members of religious congregations, priests had to refrain from medical activities, and the attempt by some medical doctors, Catholic as well as Protestant ones, to maintain or regain the academic connection between a

81 Cf. Ferdinand Doelle, Das St. Johannis-Hospital in Bonn. Festschrift zu seinem 75jährigen Bestehen (Bonn, 1924); Hugo Stursberg, 100 Jahre St. Johanneshospital in Bonn $1849-$ 1949 (Bonn, 1949).

82 Leading figures were the Archbishops of Cologne and Breslau, Johannes von Geissel and Melchior von Diepenbrock, and the most famous proponent of Catholic social teaching, the bishop of Mainz, Wilhelm Emmanuel von Ketteler. For Geissel as adherent of the medieval hospital cf. Gatz, Kirche, p. 41; for Diepenbrock as supporter of religious congregations cf. Antoni Kiełbasa, "Die Restauration der Orden unter Bischof Melchior von Diepenbrock (1845-1853)", Archiv für schlesische Kirchengeschichte, 59 (2001), 247-270, for Ketteler's social work in general cf. Ludwig Lenhart, Kettelers literarische, staats-, sozial- und kirchenpolitische Initiative in seiner und unserer Zeit. Eine literargeschichtliche Studie zu seinem Schriftum. Bischof Ketteler: Staatspolitiker, Sozialpolitiker, Kirchenpolitiker, vol 1 (Mainz, 1966), for his involvement with hospitals Wilhelm Emmanuel von Ketteler, Sämtliche Werke und Briefe, 11 vols (Mainz, 1977-2001), especially "Hülferuf zur Errichtung eines katholischen Krankenhauses in Berlin (1850)", vol I, 1, pp. 93107; "Beleuchtung des Gemeinderäthlichen Commissionsberichtes über die Verhältnisse des Vincenz-Hospitals zu den Ortsfremden und den städtischen Hospizien (1864)", vol I, 5, pp. 591-603; many letters on hospitals in Beckum, Berlin and his own diocese Mainz, cf. index. 
scientific and a philosophical or religious description of the world, finally failed, when natural philosophy was overcome by natural sciences in all the German faculties of medicine. It might be speculated that nursing was less affected by the natural sciences than medicine and therefore more easily offered this niche in modern society for devote women.

In a secularised way, the view that religion could profit from medicine, but not so much the other way round, remained dominant for more than a century - on both the medical as well as on the theological side. This tendency of making medicine serve the Christian religion concerns especially a more and more independent part of medicine, namely psychological knowledge, e.g. in counselling, and modern medicine by mission doctors and hospitals in overseas missions. Only the recent interest in spiritual aspects of health and healing, scientifically investigated in studies on placebo or psycho-neuro-immunology, has again changed the direction of the possible relationship between medicine and religion. Thus esoteric and charismatic movements repeat a central idea of the enlightenment era, although on a more psychological level: religion serving medicine and health.

Walter Bruchhausen is Senior Lecturer at the Institute for Medical History, Bonn University, Germany.

\section{Acknowledgements}

I wish to thank the participants of the session at the EAHMH conference in Paris 2005 where I presented the paper, the anonymous reviewer and Dr. Sebastian Stork, Aachen, for their careful listening or reading resp. and the valuable comments. 